\title{
Reproductive biology of Artibeus fimbriatus Gray 1838 (Chiroptera) at the southern limit of its geographic range
}

\author{
Camila S. Lima ${ }^{1,2^{*}}$ \& Marta Elena Fabián ${ }^{I}$ \\ ${ }^{1}$ Laboratório de Mastozoologia, Instituto de Biociências, Programa de Pós-Graduação em Biologia Animal, \\ Universidade Federal do Rio Grande do Sul, Av. Bento Gonçalves, n.9500/43435, Agronomia, \\ CEP: 91.501-970, Porto Alegre, RS, Brazil. \\ ${ }^{2}$ Laboratório de Biodiversidade, Conservação e Ecologia de Animais Silvestres, Programa de Pós-Graduação em \\ Ecologia e Conservação, LABCEAS, Universidade Federal do Paraná,81531-970, Curitiba, PR, Brazil. \\ *Corresponding author: camila.sdlima@gmail.com
}

LIMA, C., FABIAN, M. E. Reproductive biology of Artibeus fimbriatus Gray 1838 (Chiroptera) at the southern limit of its geographic range. Biota Neotropica. 16(4): e20160231. http://dx.doi.org/10.1590/1676-0611-BN-2016-0231

\begin{abstract}
Bats of the Phyllostomidae family exhibit different reproductive patterns in Neotropical regions and the strategy adopted depends on the regional climate. Here we studied the reproductive biology of Artibeus fimbriatus at the southern limit of their distribution in Brazil. This region has no rainy season, and the climate is characterized by high temperatures and variable photoperiods. We examined 129 A. fimbriatus females over several months, and used histological procedures where necessary in order to determine whether bats were pregnant. Females exhibited a long reproductive period and were pregnant from June until February. The reproduction events were found to be dependent on the photoperiod, but independent of annual accumulated precipitation. Our results show that at the southern limit of their distribution, A. fimbriatus exhibit seasonal-dependent reproductive patterns, with parturition events occurring during spring and summer, in which the days are longer and temperature is warmer.
\end{abstract}

Keywords: Phyllostomidae; Photoperiod; Reproduction; Seasonal.

\section{Biologia reprodutiva de Artibeus fimbriatus Gray 1838 (Chiroptera) no limite sul de sua distribuição geográfica}

\begin{abstract}
Resumo: Os morcegos Phyllostomidae apresentam diferentes padrões reprodutivos no Neotropico e a estratégia adotada depende do clima regional. Neste trabalho nós estudamos a biologia reprodutiva de $A$. fimbriatus no Brasil, na região que determina o limite sul de sua distribuição geográfica, onde não há estação chuvosa e o clima é caracterizado por variações na temperatura e fotoperíodo. Nós examinamos 129 fêmeas de $A$. fimbriatus e utilizamos procedimentos histológicos, quando necessário, para classificar as fêmeas como prenhe ao longo dos meses. As fêmeas exibem um longo período reprodutivo e estão grávidas de junho até fevereiro. Nossos resultados mostram que as fêmeas de $A$. fimbriatus apresentam uma estratégia reprodutiva que é dependente da sazonalidade com os nascimentos ocorrendo quando os dias são mais longos e a temperatura é maior (primavera e verão), no limite sul de sua distribuição geográfica.
\end{abstract}

Palavras-chave: Phyllostomidae; Fotoperiodo; Reprodução; Sazonal.

\section{Introduction}

Phyllostomidae are a family of Neotropical bats that are distributed from southern United States to northern Argentina. Within this wide geographic range they inhabit a great diversity of habitats in tropical and subtropical regions, and therefore, are submitted to a variety of abiotic factors, such as variations in latitude, temperature, rainfall and photoperiods (Fleming et al. 1972; Beguelini et al. 2013a). In response to these factors, bats of the Phyllostomidae family have evolved different reproductive patterns in Neotropical regions, such as seasonal polyestry, aseasonal polyestry and monoestry (Fleming et al. 1972; Estrada \& Coates-Estrada 2001). Considering the high diversity of bats in this region, the available information about their reproductive biology is lacking (Zortéa 2003), and only few species have had their reproductive aspects analyzed in detail (Godoy et al. 2014).

Reproduction in bats is energetically expensive and is strongly associated with specific environmental conditions (Wilson 1979). Thus, in areas where food production is seasonal, bats meet their energetic requirements for reproduction during periods of maximum food availability (Racey \& Entwistle 2000). Bats from temperate latitudes reproduce during periods of higher temperatures, when there is increased abundance of insects. In tropical regions, however, reproductive periods are associated with the rainy season, because variations in rainfall may affect the seasonality of food (Fleming et al. 1972; Racey \& Swift 1985). Therefore, variations 
in rainfall in the Neotropics affect food availability, directly interfering with the reproductive cycles of the bats over their distribution area and consequently, sub-populations may exhibit different reproductive patterns (Crichton \& Krutzsch 2000).

Artibeus fimbriatus Gray 1838 is a Phyllostomidae bat with a wide geographic distribution, found in east Paraguay, Northwest Argentina and in Brazil, from Bahia to Rio Grande do Sul (Rui \& Fabián 1999). Although most studies that have investigated tropical species generally focus on aspects of female reproduction (Beguelini et al. 2013b), the reproductive biology of $A$. fimbriatus is poorly studied and is only known in a region in southeastern of Brazil (Ésberard et al. 1998). The southern limit of the geographic range of this species is the south of Brazil, where the climate differs from other regions due to the absence of a rainy season, in addition to its characteristic high variability in temperatures and photoperiods (Kuinchtner \& Buriol 2001; Alvares et al. 2013).

There is a lack of information on the reproductive biology of A. fimbriatus, and on the effect of the different environment at the southern limit its distribution. Therefore, the objective of this study was to investigate the reproductive biology of $A$. fimbriatus females at their southern limit, and their relationship with environmental factors. Specifically, we aimed to determine: (1) the annual period of female $A$. fimbriatus reproduction at the southern limit of their distribution; and (2) whether the reproductive events are associated with the photoperiod, temperature or annual accumulated precipitation of this region.

\section{Materials and methods}

We investigated specimens that had been deposited in scientific collections to investigate the reproductive pattern of $A$. fimbriatus females. These specimens had been deposited at the University of Rio Grande do Sul and Fundação Zoobotânica do Rio Grande do Sul, and were collected between 1989 and 2011. The specimens were from Brazilian localities at the southern limit of the species distribution, located at $28^{\circ} 26^{\prime} 06.94^{\prime \prime} \mathrm{S}$

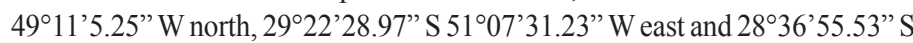
$49^{\circ} 01$ ' 31.73 " W west. These regions are characterized by the absence of a rainy season. Instead, the annual accumulated precipitation is constant throughout the year, and the climate (Köppen $\mathrm{Cfa}$ ) is characterized by high temperatures and photoperiods that vary between the four well-defined seasons.

We determined the age of females by verifying their epiphyseal ossification, and only adults were included in this study (Anthony, 1988). We analyzed their gonads to determine whether the females were pregnant. Histological confirmation was performed on some females to confirm the initial stages of pregnancy. The histological slides were prepared with a Leica ${ }^{\circledR}$ Historesin Embedding Kit or paraffin and were stained with hematoxylin and eosin. Females were classified as either lactating, pregnant, pregnant and lactating or inactive. Fetuses were measured to determine their developmental stage (Reis 1989), and were classified into five groups: group I, initial stages of pregnancy (histologically confirmed); group II, less than $1 \mathrm{~cm}$; group III, between 1 and $2 \mathrm{~cm}$; group IV, between 2 and $3 \mathrm{~cm}$; and group $\mathrm{V}$, between 3 and $4 \mathrm{~cm}$.

We used generalized linear models (GLM) with a binomial distribution to test the effect of the photoperiods and annual accumulated precipitation on the probability of reproductive events over the year. For the residual analysis and model validation, we followed the method described by Zuur et al. (2009). The photoperiods, annual accumulated precipitation (hereafter called rainfall) and temperature data were obtained from the Brazilian National Weather Institute (INMET). All analyses were performed using R software (R Development Core Team 2012) with the lme4 package (Bates et al. 2015).

\section{Results}

A total of 129 specimens were included in the analysis. Female $A$. fimbriatus bats were found to be pregnant between June and February (Figure 1) in the south of their geographical distribution range. The reproduction events were dependent on the photoperiod $(P=<0.001)$, and were independent of the annual accumulated precipitation $(P=0.83$; Figure 2$)$. We only included the photoperiod and rainfall for this analysis as photoperiod and temperature are correlated. As days become longer, the temperature also increases, and therefore, the probability of pregnancy is higher.

Fetuses at different developmental stages were observed throughout the year. Fetuses in advanced stages were found in September and February, whereas fetuses were smaller during the other months of the year (Figure 3 ). This may suggest the existence of two distinct parturition events during the year. Thus, our results show that $A$. fimbriatus females exhibit a seasonal reproductive strategy, with parturition events occurring around September and October (spring) and February (summer) when the days are longer and the temperature is warmer at the southern limit of their geographic range.

\section{Discussion}

Artibeus fimbriatus exhibits seasonally-dependent reproduction at the southern limit of its geographic range, and parturition events occur in September and October (spring) and February (summer), when the days are longer and temperature is warmer. The only previous study that has focused on the reproduction of $A$. fimbriatus was performed in a tropical

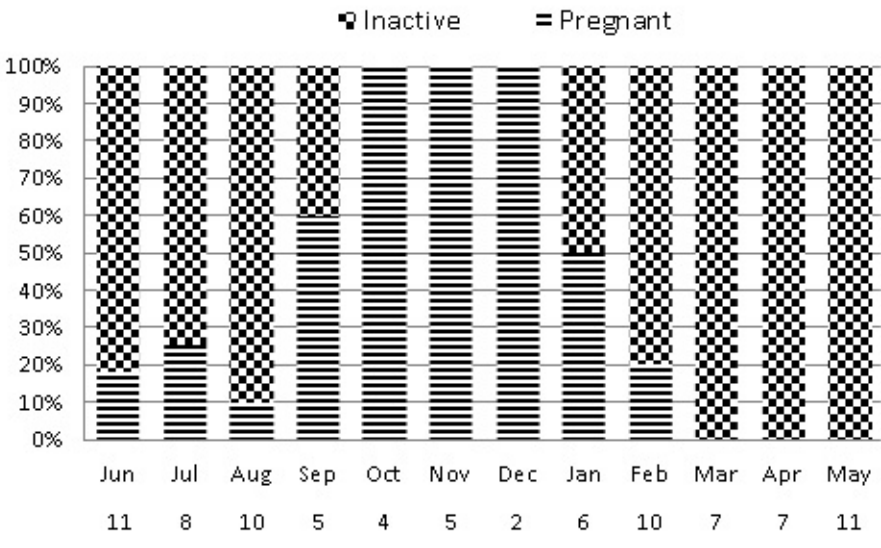

Figure 1. Reproductive status of Artibeus fimbriatus females at the southern limit of their distribution over different months of the year.

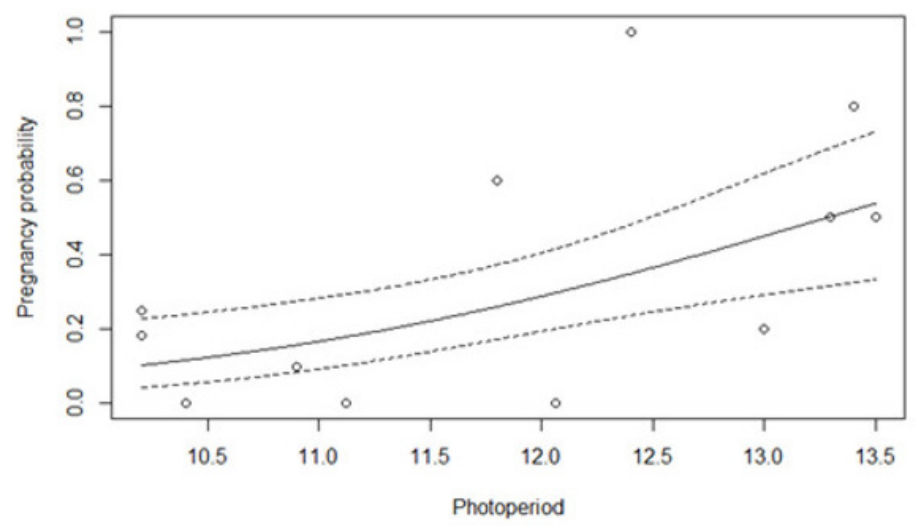

Figure 2. Relationship between reproductive events (pregnancy probability) and photoperiods at the southern limit of Artibeus fimbriatus distribution. 
aroup I \%group II $*$ group III 9 group IV $=$ group V

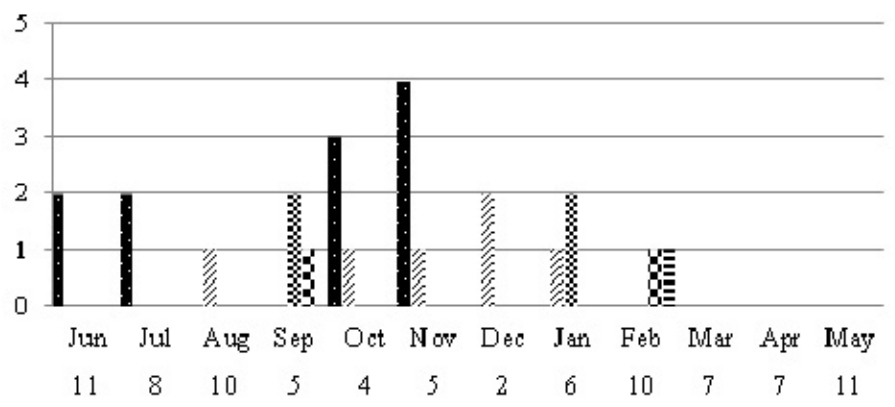

Figure 3. Different developmental stages of Artibeus fimbriatus fetuses over different months of the year.

area in Brazil (Rio de Janeiro state), where the species was also reported to exhibit seasonal reproduction, with the parturition events occurring in the rainy season (Esbérard et al. 1998). Other species of the Artibeus genus, including A. lituratus and A. jamaicensis Leach, 1821, also show seasonal reproduction, with the highest rates of pregnancy observed during the warmest seasons in Panama (Fleming et al. 1972; Bonaccorso 1978), Venezuela (Sosa \& Ramoni-Perazzi 1995) and in different localities of Brazil (Taddei 1976; Willig 1985; Reis 1989). This pattern has also been observed for other species of the Phyllostomidae family, such as Uroderma bilobatum Peters, 1866, Carollia perspicillata Linnaes 1758 (Fleming et al. 1972), Sturnira lilium (E. Geoffroy, 1810) and Platyrrhinus lineatus E. Geoffroy, 1819 (Estrada \& Coates-Estrada 2001; Stoner 2001; Costa et al. 2007).

The reproduction of bats is usually synchronized so that parturition and lactation events occur during periods of highest food availability, which coincide with periods of highest rainfall in tropical regions (Fleming et al. 1972; Willig 1985; Zortéa 2003). At the southern limit of A. fimbriatus distribution there is little variation in rainfall, however, the photoperiod and temperature can vary significantly (Kuinchtner \& Buriol 2001; Alvares et al. 2013). Within these localities we found that the parturition events occur in the spring and summer, when days are longer and the temperature is warmer. Synchronizing parturition and lactation with spring and summer in the south of Brazil, a region in which winter brings low temperatures, also increases the survival rate of growing pups (Racey \& Swift 1985). In addition, spring and summer likely correspond to periods of higher food availability in the south of Brazil. While there is no phenological information in the literature about the diet of A. fimbriatus in these regions, it is known that the abundance of insects is higher in spring and summer (Fabián et al. 1990), which are consumed by Artibeus as part of their diet (Passos et al. 2003; Passos \& Graciolli 2004).

Female $A$. fimbriatus bats have a long reproductive period of 9 months, which lasts from June until February at the southern limit of its geographic range. Ésberard et al. (1998) also reported that the reproductive period of A. fimbriatus in southeast Brazil lasts about 9 months, however, they reported that the reproductive period lasts from July until March. While the reproduction period of $A$. fimbriatus appears to be the same for these two localities, the reproduction period of other species within the Phyllostomidae family may vary. In Costa Rica, A. jamaicensis was reported to have a 9-month reproduction period. In southeast Brazil, Sturnira lilium was reported to have an 11-month reproduction period (Godoy et al. 2014) and Platyrrhinus lineatus presented a 10-month reproduction period (Costa et al. 2007).

Seasonal polyestry is the most common reproductive strategy in Phyllostomidae bats, with females exhibiting bimodal peaks for pregnancy and also for lactation, as well as monthly increases in embryo size
(Fleming et al. 1972). Our data only allowed us to determine the period in which A. fimbriatus reproduces at the southern limit of its geographic range, in addition to the embryo size. We were unable to collect information about the lactation period, as the analyzed specimens were from scientific collections, therefore, we cannot verify that $A$. fimbriatus have a bimodal pregnancy pattern. However, Ésberard et al. (1998) also concluded that A. fimbriatus exhibit seasonal reproduction, and suggested that the species may exhibit a seasonally polyestry with bimodal peaks. Therefore, although the results presented from our study and the study by Ésberard et al. (1998) are informative about the reproductive biology of A. fimbriatus, these questions remains to be answered. A bimodal reproductive pattern has also been observed for other Artibeus species, including A. lituratus in Panama (Fleming et al. 1972; Bonaccorso 1978), Venezuela (Sosa \& Ramoni-Perazzi 1995) and Brazil (Taddei 1976; Willig 1985; Reis 1989). This reproductive pattern has also been recorded for other species of Phyllostomidae, including Uroderma bilobatum Peters, 1866 and Carollia perspicillata Linnaes 1758 (Fleming et al. 1972).

In conclusion, our study shows that $A$. fimbriatus exhibit seasonal reproduction at the southern limit of their distribution, coinciding with variations in seasonal photoperiods. The parturition events occur during spring and summer when the days are longer.

\section{References}

ALVARES, C.A., STAPE, J.L., SENTELHAS, P.C., DE MORAES GONCALVES, J.L. \& SPAROVEK, G. 2013. Köppen's climate classification map for Brazil. Meteorol. Zeitschrift. 22: 711-728.

ANTHONY, E.L.P. 1988. Age determination in bats. In: Ecological and behavioral methods for the study of bats (T.H. Kunz, ed.). Johns Hopkins University Press, p. 47-58.

BATES, D., MAECHLER, M., BOLKER, B. \& WALKER, S. 2015. Fitting linear mixed-effects models using lme4. J. Stat. Softw.

BEGUELINI, M.R., PUGA, C.C.I., TABOGA, S.R. \& MORIELLE-VERSUTE, E. 2013a. Annual reproductive cycle of males of the flat fruit-eating bat, Artibeus planirostris (Chiroptera: Phyllostomidae). Gen. Comp. Endocrinol. 185: 80-89.

BEGUELINI, M.R., PUGA, C.C.I., MARTINS, F.F., BETOLI, A.H.S., TABOGA, S.R. \& MORIELLE-VERSUTE, E. 2013b. Morpholical variation of primary reproductive structures in males of five families of Neotropical bats. Anat. Rec. 296: 156-167.

BONACCORSO, F.L. 1978. Foraging and reproductive ecology in a Panamanian bat community. Florida Museum Nat. Hist. 24: 359-408.

COSTA, L.M., ALMEIDA, J.C. \& ESBÉRARD, C.E.L. 2007. Dados de reprodução de Platyrrhinus lineatus em estudo de longo prazo no Estado do Rio de Janeiro (Mammalia, Chiroptera, Phyllostomidae). Iheringia, Sér. Zool. 97: 152-156.

CRICHTON, E.G. \& KRUTZSCH, P.H. 2000. Reproductive Biology of Bats. Academic Press, London.

ESBÉRARD, C.E.L., CHAGAS, A.S., LUZ, E.M., CARNEIRO, R.A., MARTINS, L. L.S.F. \& PERACCHI A.L. 1998. Aspectos da biologia reprodutiva de Artibeus fimbriatus Gray, 1838, no Estado do Rio de Janeiro, Brasil (Chiroptera, Phyllostomidae). Bol. Soc. Biol. Concepc. 69: 109-114.

ESTRADA, A. \& COATES-ESTRADA, R. 2001. Species composition and reproductive phenology of bats in a tropical landscape at Los Tuxtlas, Mexico. J. Trop. Ecol. 17: 627-646.

FABIÁN, M.E., HARTZ, S.M. \& ARIGONY H.A. 1990. Alimentação de Tadarida brasiliensis (Geoffroy, 1824) na região urbana de Porto Alegre, RS, Brasil (Chiroptera, Molossidae). Rev. Bras. Biol. 50(2): 387-392.

FLEMING, T.H., HOOPER, E.T. \& WILSON, D.E. 1972. Three Central American bat communities: structure, reproductive cycles, and movement patterns. Ecology 53: 555-569.

GODOY, M.S.M., CARVALHO, W.D. \& ESBÉRARD, C.E.L. 2014. Reproductive biology of the bat Sturnira lilium (Chiroptera, Phyllostomidae) in the Atlantic Forest of Rio de Janeiro, southeastern Brazil. Brazilian J. Biol. 74: 913-922. 
KUINCHTNER, A. \& BURIOL, G.A. 2001. Clima do Estado do Rio Grande do Sul segundo a classificaçao climática de Koppen e Thornthwaite. Discip. Sci. 2: $171-182$.

WILLIG, M. 1985. Reproductive patterns of bats from caatingas and cerrado biomes in northeast Brazil. Brazil. J. Mamm. 66: 668-681.

PASSOS, F.C. \& GRACIOLLI, G. 2004. Observações da dieta de Artibeus lituratus (Olfers) (Chiroptera, Phyllostomidae) em duas áreas do sul do Brasil. Rev. Bras. Zool. 21: 487-489.

PASSOS, F.C., SILVA, W.R., PEDRO, W.A. \& BONIN, M.R. 2003. Frugivoria em morcegos (Mammalia: Chiroptera) no Parque Estadual Intervales, sudeste do Brasil. Rev. Bras. Zool. 20: 511-517.

RACEY, P.A. \& ENTWISTLE, A.C. 2000. Life-history and reproductive strategies of bats. In: Reproductive Biology of Bats (E.G. Krichton, \& P.H. Krutzsch, eds.). Academic Press, London, p. 363-414.

RACEY, P.A. \& SWIFT, S.M. 1985. Feeding ecology of Pipistrellus pipistrellus (Chiroptera: Verspertilionidae) during pregnancy and lactation. J. Anim. Ecol. 54: 205-215.

REIS, S.F. 1989. Biologia reprodutiva de Artibeus lituratus (Olfers, 1818) (Chiroptera: Phyllostomidae). Rev. Bras. Biol. 49: 369-372.

RUI, A.M. \& FABIÁN, M.E. 1999. Distribuição geográfica e análise morfológica de Artibeus lituratus Olfers e de Artibeus fimbriatus Gray (Chiroptera, Phyllostomidae) no Rio Grande do Sul, Brasil. Rev. Bras. Zool. 16: 447-460.
SOSA, M. \& RAMONI-PERAZZI, P. 1995. Padron reproductivo de Artibeus jamaicensis Leach, 1821, y A. lituratus (Olfers, 1818) (Chiroptera: Phyllostomidae) en una zona arida e los Andes venezolanos. Rev. Bras. Biociências 55: 705-713.

STONER, K.E. 2001. Differential habitat use and reproductive patterns of frugivorous bats in tropical dry forest of northwestern Costa Rica. Can. J. Zool. 79: 1626-1633.

TADDEI, V.A. 1976. The reproduction of some Phyllostomidae (Chiroptera) from the Northwestern region of the State of São Paulo. Bol. Zool. Univ. São Paulo 1: 313-330.

WILSON, D.E. 1979. Reproductive patterns. In: Biology of Bats of the New World Family Phyllostomidae (R.J BAKER., J.K. JONES. \& D.C. CARTER, eds). Special Publications Museum, Texas Tech University, p. 317-378.

ZORTÉA, M. 2003. Reeproductive patterns and feeding habits of three nectarivorous bats (Phyllostomidae: Glossophaginae) from the Brazilian Cerrado. Brazilian J. Biol. 63: 159-168.

ZUUR, A.F., IENO, E.N., WALKER, N.J., SAVELIEV, A.A. \& SMITH, G.M. 2009. Mixed Effects Models and Extensions in Ecology with R. Springer, New York.

Received: 17/07/2016

Revised: 02/10/2016

Accepted: 06/10/2016 